\title{
Financial Development and Economic Growth in Selected Asian Economies: A Dynamic Panel ARDL Test
}

\author{
Shravani and Supran Kumar Sharma
}

\begin{abstract}
The present endeavor measures the extent of the nexus between financial development and economic growth by utilizing annual macroeconomic panel data for selected 14 Asian economies. The study focuses on the link between the indicators of financial development and economic growth. The results of panel cointegration analysis suggest that there is two-way cointegration relationship from GDP to GCF and BM in short-run as well as in long-run however, the relationship is one-way, that is, from GDP to DCPS as well as from GDP to DCBS. The findings of the present study establish strong indications of the positive long-run relationship among all the selected indicators of financial development and economic growth. Moreover, the present attempt also indicates that gross capital formation and broad money are critical for economic growth and suggests that upliftment of economic growth of the economies improves the development of financial sector
\end{abstract}

KEY WORDS: $\quad$ causality, banking sector, panel unit root, panel ARDL.

JEL Classification: G21, C23, O40.

Shri Mata Vaishno Devi University, India

\section{Introduction}

Economic development of a country accelerates and enhances the quality of life of the inhabitants by increasing productive capacity and expanding its core infrastructure base. Enormous efforts have been put forth by various studies and policy-makers to scrutinize different alternatives which are instruments in the enhancement of economic growth. Of the possible factors contributing towards economic growth, the role of financial sector has begun to receive more attention during the recent past. Earlier, the writings of McKinnon (2010) and Shaw (1973) initiated the discussion

Correspondence concerning this article should be addressed to: Supran Kumar Sharma, Shri Mata Vaishno Devi University, Katra, Jammu and Kashmir, India. E-mail: shravanisharma06@gmail.com by presenting the hypothesis of a strong relationship between financial development and economic growth. Financial development includes an improvement in the financial transactions with simultaneous increase in the volume of financial services of banks and other financial intermediaries (Hussain \& Chakraborty, 2012). To appreciate and analyze the contribution of financial sector towards the economic growth of an economy, it is essential to understand the critical functions of this sector towards the upliftment of the economy. One of the most prominent functions of the financial sector includes providing credit facility to the entrepreneurs and farmers as they hardly have enough of their own capital to carry out investments themselves. Apart from this, the benefits are also extended to the savers by providing a shield against the large de- 
gree of risk by facilitating transfer of resources from savers to investors. The financial system including banks and other financial intermediaries provides an adequate solution to the financial issues of small savers by accumulating capital from them and distributing it further to the most productive uses and also supervising the appropriateness of this financial circle. A sound financial system efficiently identifies the appropriate projects that need to be funded by evaluating the respective worth of the upcoming projects (Schumpeter, 1911). In brief, an appropriately functioning financial system, distributes risk rationally and in-turn contributes towards making economies more resilient to the unforeseen shocks. A well-developed and functional financial system enhances the effectiveness of financial intermediation by reducing operational as well as informational expenditure as these are the essential requirements for fast, sustainable and long run economic growth of an economy (Holden \& Howel, 2009; Chakroborty \& Mukherjee, 2012). Uncovering the level and direction of relationship between financial development and economic growth is crucial as it provides the smooth path for the implementation of policies which can have a broader impact on the growth and consequently, on the standard of living of the inhabitants of an economy. A comprehensive study by World Bank (1989) for those developing countries which have embarked on financial development programs supported the contention that 'financial development matters for economic growth'. Contrary to this, the other side of the coin depicts different picture as Lucas (1988) and Singh (1997) claimed that economists 'badly overstressed' the role of financial system towards the economic growth of an economy.

Taking into consideration the above-mentioned viewpoints, the section-II of the present study discusses a whole lot of such contrasting views on the relationship of financial development and economic growth. It is essential to analyze the direction of the association so that proper attention may be paid to the factors which are leading towards the ideal growth path of an economy. If economic growth is governed by financial development then appropriate policies of financial sector development are required to be framed both at macro as well as micro level, moreover, in the other case if economic growth governs financial development then polices and economic growth-oriented programs need to be framed accordingly.

Keeping above discussion in view, the elementary objective of the present paper is to re-examine the nature of the finance-growth relationship for the selected Asian economies and simultaneously to provide better empirical insights by considering the applications of novel panel econometric methods.

In the recent years most of the Asian economies have shown a gradual increase in the economic growth. Apart from this, the Asian economies have shown tremendous improvement in the growth pattern of the financial sector as well (see Table 1). The rapidly growing financial sector on one side and improvement in the growth pattern of the Asian economies on the other side, create inquisitiveness for identifying the relationship between the two constructs. Since, as such very scant literature is available which has considered a mix of fully developed countries like Thailand, Singapore, Malaysia, Macao etc. which are also widely referred as "Asian Dragons" and Pakistan, Bangladesh, which are facing serious hindrance in sustaining their normal growth rates. Studying the varying nature of growth rates of different economies and identifying their linkage with the financial development status of the economy are the pivotal questions which the present study attempts to resolves.

Moving further, the rest of the paper is organized primarily into five sections. Section 2, attempts to summarize the existing literature related to the relationship between financial development and economic growth. Section 3 discusses the research methodology applied to assess this relationship and Section 4 discusses the empirical results, while Section 5 summarizes the whole study followed by relevant policy suggestions and future research avenues on the issues in discussion.

\section{Review of Literature}

The compositions on the relationship between financial development and economic growth could be traced way back from the work of Schumpeter (1911), Robinson (1952) and many more. A remarkable number of recent studies (Al-Yousif, 2002; Darrat, 1999; Demetriades \& Hussein, 1996; Luintel \& Khan, 1999; Ghirmay, 2004) utilized data from different countries to examine the aforesaid issue. The previous studies differ in terms of the country sets considered, methods applied 
Table 1. A Snapshot of the Studies Regarding the Relationship Between the Financial Development and Economic Growth

\begin{tabular}{cccc}
\hline S.No. & Tools/Technique \\
Used & Variables Used & $\begin{array}{c}\text { Relationship } \\
\text { Established }\end{array}$ \\
\hline
\end{tabular}
Goldsmith (1969) Correlation anal- (i) Output of economy (ii) Development of ysis

2

$$
\text { Waqabaca (2004) }
$$

(i) Unit root (ii)

3 Rioja and Valev (2004) co-integration techniques

(i) Ratio of financial assets to GDP, (ii) Ratio of liquid liabilities to GDP (iii) Ratio of private sector credit to GDP (iv) Level of real GDP (v) Level of real GDP per capita (iv) Ratio of investment to GDP.

(i) GMM panel econometric technique

(i) GMM panel econometric technique

(i) Bootstrap Panel Granger causality

(i) Initial income per capita; (ii) Average years of schooling; (iii) Government size (government spending/ GDP), (iv) Openness to trade ((exports + imports)/GDP); (v) the Average inflation rate; (vi) Black market premium

(i) Private Credit, (ii) Bank Competition and (iii) Public Credit.

(i) Ratio of liquid liabilities to GDP (ii) Ratio of private sector credit to GDP (iii) GDP
Distributed lag approach (i) Initial real GDP; (ii) Gross fixed capital formation;(iii) Population Growth, (iv) Openness to Trade; (v) Government expenditure as a share of (vi) Life Expectancy and (vii) Inflation (viii) Ratio of Liquid Liabilities to nominal GDP (ix) Ratio of commercial bank assets to the sum of commercial bank assets and central bank assets and the ratio of bank credit to the private sector to GDP
$E G->F D$

$E G->F D$

Positive effect of financial development on economic growth for developed countries

FD-> EG

FD->EG (Malaysia, Indonesia, Korea, Singapore, Thailand, Taiwan and (hina) EG->FD (Malaysia) $\mathrm{FD} \neq \mathrm{EG}$ (Philippines, India and Japan)

FD->EG 
Table 1. A Snapshot of the Studies Regarding the Relationship Between the Financial Development and Economic Growth (Continued)

\begin{tabular}{|c|c|c|c|c|}
\hline S.No. & Study & $\begin{array}{c}\text { Tools/Technique } \\
\text { Used }\end{array}$ & Variables Used & Relationship \\
\hline
\end{tabular}

7

(2015)

\author{
(i) Cross Sectional \\ Dependence, (ii)
} Cointegration

\begin{abstract}
Rana and Barua
\end{abstract}

(ii) FMOLS

(i) Domestic Credit Provided by Financial

Sector (ii) Total Debt Services (iii) Gross Domestic Savings (iv) Broad Money (v)

Trade Balance.

(i) Domestic credit by banking sector/ GDP (ii) Domestic credit to private sector/GDP, (iii) Net inflows of FDI/GDP (iv) Market capitalization (v) Fixed capital formation/GDP(vi) investment/GDP (vii) Inflation in consumer prices/GDP
Alom (2018)
(i) Pedroni
(ii) Johansen
co-integration
(iii) panel based
Granger causality

(i) M2 (ii) Real interest rate (iii) Domestic credit to private sector (iv) GDP
FD-> EG

FD->EG

$F D<->E G$ for estimation as well as the financial development and economic growth indicators chosen for their respective research. As far as the measure of financial development indicators is concerned, apart from the above mentioned studies, some studies such as King and Levine (1993), Levine and Zervos (1999), Levine (1997), Ndikumana (2000), Acaravci et al. (2009), Arcand et al. (2015), Pan et al. (2016), Murari (2017), and Odhiambo and Muyambiri (2018) also focused on bank based measures of financial development, while studies like Levine (1991), Levine and Zervos (1998), Khan and Senhadji (2003), Rana and Barua (2015), and Bongini et al. (2017) focused on market based measures to study the cross country relationship.

The existing literature has defined diverse ways for classifying the relationship between financial development and economic growth; these include different classification based on the varied estimation techniques such as vector autoregression, cointegration, correlation, granger causality, etc. These studies generally found positive correlation between the indicators of financial development and economic growth, (Al-Yousif,
2002; Demetriades \& Hussein, 1996; Gouider \& Trabelsi, 2005; Gylfason \& Zoega, 2006; Levine \& Zervos, 1999).

Apart from simple correlation technique, some of the studies (Al \& Harb, 2005; Fase \& Abma, 2003; Ghirmay, 2004) have applied error correction model for reporting the causality issue. But one of the difficulties with the cross-section or simple time-series databased technique is that these techniques somehow fail to explain the issue of cross-sectional variation, dynamic behavior and the problem of endogeneity of the explanatory variables (Arizala et al., 2009).

While defining one of the limitations of grouping countries together in cross-sections, Rioja and Valev (2004) mentioned that link between finance and growth also depends on the stage of economic development of the economy. The study stated that a weak relationship was detected for developed economies, while a strong relationship uncovered for the developing economies. Similarly, Fase (2001) also suggested that financial development causes higher impact on the economic growth of developing countries than the developed countries. On the similar front, there is a great 
debate on the impact of political institutions, namely democratic versus an authoritarian administration on growth. Rodrik (1999) suggested that democracy generates higher quality of growth since it allows greater stability. Whereas, Alesina and Rodrik (1994) emphasized that autocratic systems are more efficient than democratic regimes as autocratic administration easily opposes the pressure from vested interests and redistributes the income and resources. Considering the link of financial development and economic growth Ghardallou and Boudriga (2013) suggested that democracy enhances the level of financial development in countries with strong institutional framework. Furthermore, some of the studies, by utilizing the advanced panel data for the selected Asian economies, established a strong association between the indicators of financial development and economic growth (Adusei, 2013; Beck et al., 2000; Benhabib \& Spiegel, 2000; Habibullah \& Eng, 2006 ).

Rana and Barua (2015) using the data for five Asian countries including India, Pakistan, Sri Lanka, Nepal, Bangladesh indicated that domestic credit and broad money as a whole has no significant impact on the financial development and economic growth. However, debt services and savings do significantly influence the financial development and growth nexus. Bongini et al. (2017) considering set of central, eastern and south-eastern European countries, identified that bank credit has an important and critical role in enhancing economic growth of an economy. In another study, Pan et al. (2016) identified the role of another important construct of banking industry i.e. insurance sector which can help in strengthening the financial sector. Similarly, Murari (2017) identified the relationship between financial development and economic growth in the selected south Asian economies over the period of 1980-2013 wherein the results again indicated a strong bi-directional linkage of credit to private sector and economic growth. The results supported the presence of strong and balanced financial institutions and capital formation facilitates economic growth.

Similarly, Alom (2018) in a study of five south Asian economies identified a strong cointegration between financial development and growth of the respective economies in long-run. The study also highlighted the role of optimum interest rates in achieving higher and more balanced economic growth.
By summarizing the view point of various studies regarding the relationship between financial development and economic growth, it is suggested that on one hand, there are various outlooks which suggests that development of the financial system facilitates growth of an economy and is also known as supply leading view (Ahmed \& Ansari, 1998; Beck et al., 2000; Bhattacharya \& Sivasubramanian, 2003; Calderon \& Liu, 2003; Chakraborty \& Ray, 2006; Hsueh et al., 2013; Levine, 1991; Odedokun, 1996 ). On the other hand, there are models suggesting that economic growth causes financial development, that is, demand following view as in Agbetsiafa (2003), Greenwood and Smith (1997), Kuznets (1955), Odhiambo (2008), Stem (1989), Waqabaca (2004).). Interestingly, in addition to this there is still another group of established researchers and intellectuals elaborating no significant association between development of financial sector and growth of an economy. However, Lucas (1988) argued the overstated significance of financial markets in the process of development of an economy and also highlighted the trivial part of the financial markets in the process of advancement of an economy. Thus, a third pattern emerges which in-turn implies that the two variables are causally independent (Chandavarkar, 1992; \& Bakhouche, 2007).

Besides the above three distinct causal views, another view point is a blend of both the above mentioned viewpoints. That is, a mutually causal relationship between financial development and economic growth hence suggesting bi-directional causality (Abu-bader \& Abu-Qarn, 2010; Greenwood \& Smith, 1997; Hassan et al., 2011).

The review of the vast literature on the finance growth nexus suggests that a large number of studies (Lucas, 1988; De and Guidotti, 1995 and Greenwood and Smith, 1997) at macro level have suggested conflicting outlook particularly with respect to the direction of causality (see Table 1). Besides the inconclusive results, the evidence cited so far seems to be skewed towards the developed world. Moreover, the literature also suggested that there is difference in the nature of relationship between financial development and economic growth when studied for different geographical regions, level of development and nature of governance practiced in an economy etc. The literature suggested that the evidences from Asian countries are also sparse and conflicting 
and very limited research studies have been done while focusing on few Asian economies such as Bangladesh, Pakistan, India, Sri Lanka etc. (Ang \& McKibbin, 2007; Liang \& Teng, 2006). This has created a knowledge gap as to the kind of relationship that exists between finance and growth in Asian countries. Therefore, considering the existing literature, the present paper is an attempt to validate the causal relationship between financial development and economic growth in the relatively larger set of selected Asian economies. In a broader way, the major objectives of the present study are (a) To identify whether the different indicators of financial development have any association with the economic growth and (b) To measure the existence/ direction of causality between the indicators of financial development and economic growth in selected Asian economies.

\section{Research Tools}

\subsection{Data and Variables Used}

In the recent years a lot of studies related to social science have used the panel data based research tools (Howie \& Kleczyk, 2007; Hunady, 2017). The main advantage of utilizing panel data is that it provides enough observations to estimate parameters in various multivariate analysis techniques that otherwise could not be estimated in a cross-section or time-series analysis (Hassan et al., 2011).

To fulfill the research gap regarding the study mentioning finance growth nexus in Asian economies, the present study intended to include the largest possible number of observations on the basis of regular data availability and simultaneously aimed to have a balanced panel. Thus, the study has utilized annual macroeconomic data of 14 Asian countries (details provided in Appendix 1) for the period of 1990-2015 from the database of the World Bank (2016). The novelty of the present study lies in the fact that for the present study most of the emerging eastern Asian economies have been selected, apart from them in the present study economies like Saudi Arabia and Jordan have also been selected because of their increasing growth rates patterns as depicted in the Table 1 . The present study has not selected other Asian economies like Syria, Iraq, Afghanistan etc. since the political and social environment of these economies is not stable and hence, these economies are not ideal for testing the aforementioned relationship between financial development and economic growth. Apart from this, the duration from 1990 onwards has been selected very carefully where most of the Asian economies were moving towards the implementation of financial and government reforms in the order to protect their economies from Asian financial crises. The present literature defines different indicators that can be used to represent the financial development of an economy. Among such variables, the liquid liabilities of financial intermediaries, measures of credit extended by them such as domestic credit to private sectors and ratio of domestic credit to income (De \& Guidotti, 1995; Demetriades Hussein, 1996; Luintel \& Khan, 1999) are the prominent ones. Moreover, some studies (Abu-Bader \& Abu-Qarn, 2007; Ayadi \& Arbak, 2013; Kar \& Pentecost, 2000; have focused only upon the pure financial indicators like bank credit, number of banks, number of bank accounts, bank deposits, etc. while, some other have also incorporated stock market indicators like stock market capitalization, number of share (Bena \& Jurajda, 2007; Ben et al., 2008). The proxies for economic growth tend to include the rate of GDP at constant prices, capital stock per capita, productivity per capita, etc (Beck et al., 2000; Rajan \& Zingales, 1998). In the present model, GDP at constant prices is used as a proxy for economic growth for the selected countries. The GDP at constant prices is the aggregate of gross value added by all citizen who are residing in the economy plus any product taxes and minus any subsidies (World Bank, 2013).

Although, different indicators may be used to define financial development appropriately for an economy, following the standard literature, the present study proxies the depth of the financial system by the selected variables including:-

(a) Domestic Credit to Private Sector (DCPS): The DCPS refers to financial resources provided to the private sector such as loans, purchases of nonequity securities trade credits and other accounts receivables that establish a claim for repayment (World Bank, 2016). Ghirmay (2004) put forwarded 
that private sector is an accurate measure of the functioning of financial development since it captures the quantity and quality of investment. Moreover, it has been suggested that high value of Domestic Credit to Private Sector indicates not only a higher level of domestic investment but also higher development of the financial system and in turn rapid economic growth (Levine, 2005). (b) Domestic Credit provided by Banking Sector (DCBS): The DCBS includes credit provided to different sectors on a gross basis with the exception of credit to the central government (World Bank, 2016). An economy with higher value of DCBS is said to be highly dependent on its banking sector for financing. In other words, higher DCBS implies higher financial development (Levine, 1997). (c) The present study also used the broadest definition of money, namely, Broad Money (BM) to measure the liquid liabilities of the banking system in the economy. The BM is defined as the sum of currency outside banks; demand deposits other than those of the central government; the time, savings, and foreign currency deposits of resident sectors other than the central government; checks issued to travelers; and other securities such as certificates of deposits and commercial papers (World Bank, 2016).

Apart from these financial development indicators, (d) the level of capital formation is likely to influence investment and economic growth as well. The use of Gross Capital Formation to GDP ratio (GCF) captures the development of the investment activities during the period. In the present context, the GCF is primarily considered as a common variable to study the relationship between financial development and economic growth in the selected Asian economies.

\subsection{Research Tools Applied}

The present research works with the objective to measure the extent and direction of the relationship between economic growth and selected financial development indicators by applying the following econometric tools and techniques.

\subsubsection{Cross-Sectional Dependence}

The cross-section dependence test by Breusch and Pagan (1980) is a method which tests the null hypothesis of zero dependence across the panel members and is relevant to a range of panel data with large time period and small number of cross-sections (Pata \& Terzi, 2017; Breusch \& Pagan, 1980; Sarafidis \& Wansbeek, 2012).

\subsubsection{Panel Unit Root Tests}

In the next step, the nature and tendency of panel unit root is examined for the variables under consideration. The panel unit root tests are more effective and statistically stronger than the timeseries unit root tests (Hadri, 2000; Im et al., 2003; Maddala \& Wu, 1999). The literature has categorized different panel unit root tests into the categories of homogeneous as well as heterogeneous unit root tests. The Levin et al. (2002), Breitung (2000) and Hadri (2000) type of models are categorized under homogeneous unit root tests, while Maddala and Wu (1999) and Im et al. (2003) models fall under heterogeneous unit root tests. In order to keep the focus of the present study on the countries located in the same geographical location, the data is primarily taken for Asian economies only yet these selected economies vary in terms of level and rate of growth and development. Thus, indicating that the data could be considered as heterogeneous because of the varying growth rates as well as homogeneous due to the similar geographic conditions. Hence, the present study has opted to apply both categories of test by applying the Im, Pesaran and Shin (IPS), Levin, Lin and Chu (LLC) as well as the Phillips Perron unit root tests for analyzing the stationarity properties of the data.

(i) The previously mentioned IPS test for identifying the stationarity of the data in the present attempt may be defined as:

$$
\operatorname{Var} 1_{\mathrm{pl}}=\epsilon_{\mathrm{p}} \operatorname{Var} 1_{\mathrm{pl}-1}+\sum_{j=1}^{€} \emptyset_{p j} \Delta \operatorname{Var} 1_{\mathrm{p} 1-\mathrm{j}}+\mathrm{X}_{\mathrm{p} p} p_{\mathrm{p}}+\epsilon_{\mathrm{pl}}
$$

Here, Var1 $1_{\mathrm{pl}}$ indicates the variables selected to study different relationships in the present study, $€$ is the autoregressive coefficient and $\epsilon$ is the error term. Further, $\mathrm{p}$ which ranges between $1,2, \ldots$, A reflects the data from different selected states over period 1 which ranges for the selected years $1,2, \ldots, 1_{p}$. For the equation (i) the null hypothesis is explained as:

Hypoth $0=€ \mathrm{p}=0$, for $\mathrm{p}=1,2, \ldots, \mathrm{A}$ 
The above equation specifies the presence of unit root.

Hypoth $1=\beta \mathrm{i}<0$, for $\mathrm{i}=1,2, \ldots, \mathrm{N}$.

It is to be noted that under IPS test different unit root tests are used for different cross-sections. Moreover, the IPS test requires specification of the lags and deterministic component for each cross-section in the separate $\mathrm{ADF}$ regressions.

Whereas, LLC method measures the simple regression equation of the concerned variable in differenced format:

$\Delta \mathrm{x}_{\mathrm{i}, \mathrm{t}}=\delta_{\mathrm{i}} \mathrm{x}_{\mathrm{i}, \mathrm{t}-1}+\sum_{\mathrm{j}=1}^{\mathrm{S}_{\mathrm{i}}} \emptyset_{\mathrm{i}, \mathrm{j}}^{\mathrm{i}} \Delta \mathrm{x}_{\mathrm{i}, \mathrm{t}-\mathrm{j}}^{\mathrm{w}}+\mathrm{u}_{\mathrm{i}, \mathrm{t}}+\propto_{\mathrm{i}}$

Here $\mathrm{x}$ is the variable selected to study different relationships for duration i ranging from $1,2, \ldots, \mathrm{N}$ and time for the span $1,2, \ldots, \mathrm{T}$.

The panel regression (equation 2) estimates the results for the null hypothesis $(\delta=0$, i.e. panel contains unit root). In the present attempt, different unit root estimations shall help in checking of the robustness of results of different cross-sections (Mohsin and Rivers, 2010).

\subsubsection{Panel Cointegration Tests and Causality Testing} The present study adopted the Panel Autoregressive Distributed Lag (P-ARDL) model of Chudik \& Pesaran (2013) to test for the existence of long-run and shortrun relationships between growth of the economy and the respective indicators of financial development. The choice of the ARDL methodology for this study is based on the fact that the ARDL technique is best suitable for the situation where the some of the variables are stationary at the base level and some are stationary at the first difference level, that is, where the order of integration is not same. Further, for testing the causal relationship between the variables Dumitrescu \& Hurlin (2012) Granger Causality test is utilized in order to test for Granger causality in panel dataset of Asian economies considered in the present study.

Table 2. ACGRs of GDP of the Selected Asian Economies

\begin{tabular}{|c|c|c|c|c|c|}
\hline Countries & $\begin{array}{l}\text { Growth Rate } \\
\text { (per cent) }\end{array}$ & t-Statistics & Countries & $\begin{array}{c}\text { Growth Rate } \\
\text { (per cent) }\end{array}$ & t- Statistics \\
\hline Bangladesh & 2.55 & $24.29(0.00)$ & Macao & 5.24 & $21.60(0.00)$ \\
\hline Bhutan & 3.61 & $42.06(0.00)$ & Malaysia & 2.10 & $25.38(0.00)$ \\
\hline China & 4.54 & $65.88(0.00)$ & Nepal & 1.69 & $29.29(0.00)$ \\
\hline India & 3.31 & $42.13(0.00)$ & Pakistan & 2.08 & $21.73(0.00)$ \\
\hline Japan & 0.31 & $3.55(0.00)$ & Saudi Arabia & 1.59 & $19.57(0.00)$ \\
\hline Jordan & 2.79 & $27.57(0.00)$ & Sri Lanka & 2.48 & $24.29(0.00)$ \\
\hline South Korea & 1.74 & $29.11(0.00)$ & Thailand & 1.82 & $15.15(0.00)$ \\
\hline
\end{tabular}

Note: Figures in the parentheses reflect p-value 


\section{Empirical Results and Discussion}

The present section elaborates the empirical results and explores the association between the dimensions of financial system and growth of the economy of selected Asian economies. Before identifying the association between the variables initially, an overall picture of growth of economies that is, the annual compounded growth rate is presented. ACGR is defined as the growth of a variable over a period of time while considering the trends over the period too. The ACGR scores of the GDP at constant prices of the selected countries presented in the Table 2 depict that over the period of 1990-2015, Macao has registered the highest ACGR of 5.24 per cent followed by China (4.54 per cent) and Bhutan (3.61 per cent). The lower ACGR of 0.31 per cent is portrayed by Japan. The reason for lowest ACGR values is attributed to the sustained growth of Japan over the period. As far as Macao and Bhutan are concerned, both the countries flourished in terms of growth during the $20^{\text {th }}$ century due to the development in the area of tourism and hospitality (World Tourism Organization, 2014). The sustained growth rates of most of the selected Asian economies suggests that most of the Asian economies have coped-up with their economic growth rates and the effect of Asian financial crisis is not so severe in these economies.

As a first step towards the panel data estimation, the present endeavor applies the cross-section dependence (CD) test developed by Breusch and Pagan (1980) to verify the presence of cross-section dependence in the analysis of the finance-growth nexus. Thus, both GDP at constant prices and different financial indicators are initially tested for dependence across the 14 selected countries under consideration. The pair-wise correlations which are necessary to compute the independence statistics for the Breusch-Pagan LM test are obtained from the residuals of the regression of each variable. The results of the Breusch-Pagan LM test of independence based on these correlations indicate that GDP and financial variables are not dependent across countries.

The hypothesis of cross-section independence is clearly accepted by a value of 979.5 for GDP and DCPS relation ( $p$-value significant at 1 per cent level of significance), 1066.54 GDP and DCBS relation (p-value significant at 1 per cent level of significance),
1025.54 for GDP and BM relation (p-value significant at 1 per cent level of significance) and 2157.01 for GDP and GCF relation ( $\mathrm{p}$-value significant at 1 per cent level of significance). Thus, the present study moves forward with the application of the first generation panel unit root tests. Before proceeding further with the testing of cointegration stationarity through panel unit root tests have been examined to investigate the level of integration of the concerned variables (Sharma et al., 2010). Under the IPS, LLC and PP unit root tests each selected variable in the panel of the 14 Asian countries is measured for the null hypothesis that the variable is having unit root. The results of the IPS and LLC panel unit root tests (at levels) (see Table 3) advocates that except for Broad money and Gross capital formation none of the variables is stationary in the given panel unit root test, however, for PP unit root test all the variables are non-stationary at level so considering these results the study proceeded with estimation of unit root at first difference (Onyele \& Nwokoacha,, 2016). Thus, the analysis of the model suggests that when the variables are taken at their level form, the null hypothesis of a unit root cannot be rejected for all the variables of the model and in order to receive consistent and reliable results, the non-stationary data series needs to be transformed into stationary data series.

In this way, the model is tested for stationarity at the first difference. The results of data for the test statistics at first difference reject the null hypothesis at 1 per cent level of significance and thus, it can be safely concluded that all the variables are stationary at first difference.

\subsection{The Panel ARDL Lag Determination}

Before proceeding with the estimation of cointegration between the variables, identification of optimal lag length for further estimation process is an essential decision to be made. In view of the fact that, the results from the Panel ARDL test might be sensitive to the selected lag length, so identifying the most favorable lag length is essential for robustness of the findings (Konya, 2006). Moving further with the selection process of optimal lag length an explicit test of panel vector autoregression (PVAR) originally developed by Holtz-Eakin et al. (1988) especially for the data with a limited time span and a larger cross- 
Table 3. Panel Unit Root Test

IPS

LLC

PP

\begin{tabular}{|c|c|c|c|c|c|c|}
\hline Statistics & At Level & $\begin{array}{c}\text { At First } \\
\text { Difference }\end{array}$ & At Level & $\begin{array}{c}\text { At First } \\
\text { Difference }\end{array}$ & At Level & $\begin{array}{c}\text { At First } \\
\text { Difference }\end{array}$ \\
\hline & t- Statistics & t-Statistics & t- Statistics & t-Statistics & t- Statistics & t-Statistics \\
\hline DCPS & $0.72(0.76)$ & $-6.97(0.00)$ & $-0.67(0.18)$ & $-5.61(0.00)$ & $15.13(0.97)$ & $157.99(0.00)$ \\
\hline DCBS & $0.76(0.77)$ & $-6.87(0.00)$ & $-0.78(0.21)$ & $-5.62(0.00)$ & $15.43(0.97)$ & $161.64(0.00)$ \\
\hline BM & $-1.37(0.09)$ & $-7.57(0.00)$ & $3.03(0.00)$ & $-6.87(0.00)$ & $31.27(0.22)$ & $195.46(0.00)$ \\
\hline GCF & $-1.78(0.03)$ & $-7.93(0.00)$ & $-2.57(0.01)$ & $-6.46(0.00)$ & $32.77(0.24)$ & $191.99(0.00)$ \\
\hline GDP & $4.23(1.00)$ & $-6.33(0.00)$ & $0.20(0.58)$ & $-5.75(0.00)$ & $12.19(0.99)$ & $145.46(0.00)$ \\
\hline
\end{tabular}

Note: Figures in the parentheses reflect p-value

sectional dimension has been applied separately for identifying optimal lag-length for each of the variables. As used in most of the panel data studies the order of lag selection in the present study is based upon Akaie Information Criteria (AIC) and Schwarz Criteria (SC) and based on the results the optimal lag length for each of the variable is depicted in Table 4.

\subsection{The Panel ARDL Regression Model and Dumitrescu-Hurlin Test of Causality}

Four different P-ARDL relationships are tested including (a) the relationship between GDP and DCPS; (b) the relationship between GDP and BM; (c) the relationship between GDP and DCBS; and (d) the relationship between GDP and GCF.

For the above relationship, the results of the panel ARDL test as presented in Table 5 suggests that in long-run except for DCPS and DCBS both GCF and $\mathrm{BM}$ are statistically significant and hence are supportive in elucidation of the overall economic growth of the economies. The results imply that an increase in these statistically significant variables will directly enhance the growth of the economies in the long-run. However, in another model of identification of the impact of GDP on rest all of the variables the relationship is found to be statistically significant at 1 per cent level of significance. Hence, suggesting longrun association of GDP on the respective selected variables. After identifying the long-run relationship of the variables with economic growth, it is suitable to study the associated relationship further in shortrun as a next step.

In short-run the results of the panel ARDL indicates that coefficients of GCF and BM are statistically significant at 1 per cent level of significance. Further, the cointegration in GCF is reinforced by the negative and statistically significant short-run coefficient represented as contQ1. In the 
Table 4. The Panel ARDL Lag Determination

\begin{tabular}{lcc}
\hline Lag & AIC & SC \\
\hline 0 & -22.124 & -22.051 \\
1 & & $-22.201^{*}$
\end{tabular}

present study, the results of the $\mathrm{p}$-value of the Wald test for $\mathrm{GDP}=f(\mathrm{GCF})$ and $\mathrm{GDP}=f(\mathrm{BM})$ model under consideration are statistically significant which suggest that all the respective coefficients are equal to zero. Therefore, the result validates that present study rejects the null hypothesis of no cointegration and hence reinforce the existence of cointegration between the two. Further, the p-value of F-statistics is also above the upper band of the critical value of 4.09 (Pesaran \& Pesaran, 1997). Further, in another model where the impact of the GDP is studied for all the variables. The study unveiled that for all the cases including $\mathrm{GCF}=f(\mathrm{GDP}), \mathrm{BM}=f(\mathrm{GDP})$, DCPS $=f(\mathrm{GDP})$ and DCBS $=f(\mathrm{GDP})$ there is shortrun cointegrating relationship from GDP to the respective variable. Hence, the study indicates that there is two way cointegration relationship from GDP to GCF and BM in short-run as well as in longrun however, the relationship is unidirectional, that is, from GDP to DCPS as well as DCBS. The same is reinforced by the estimates of f-statistics values in Wald-test.

The estimated coefficient of GCF remains positive and statistically significant at 1 per cent level of significance suggesting that higher the capital formation higher will be economic growth. This suggests that the financial sector more or less contributes towards the expansion of real sector. As far as the broad money is concerned, the results of the present study indicates that the monetization is indeed important as circulating currency as well as public deposits in banks affects GDP (Ogren, 2008). The results of Granger Causality depicts a two-way granger causality between GCF and GDP and also in case of BM and GDP. However, a one-way granger causality is reflected from GDP to DCPS and DCBS Thus, it reinforces the results of panel ARDL.

\section{Conclusions and Recommendations}

By utilizing annual macroeconomic data for a sample of the selected Asian countries, the present study investigates the level and direction of the nexus between financial development and economic growth for the period 1990 to 2015 .

The theoretical significance of the findings of the present study is noteworthy as it has attempted to broaden the scope of growth-finance link by focusing on the emerging East Asian economies meanwhile by using recently developed panel cointegration technique combined with more expanded panel datasets to develop more empirical policy implications. Overall, the study indicates that despite the Asian financial crisis in 1997 the financial sector and the growth of the economy of the selected countries moved rapidly in a consistent manner with the help of financial and economic reforms.

The results of the panel ARDL analysis suggested that economic growth and financial development indicators are cointegrated and thus, there exists long-run relationship between them. One of the key outcomes of the study is the identification of positive relationship between indicators of financial development and the economic growth. The estimations of the dynamic panel ARDL analysis, however, accentuate the importance of the financial sector and more specifically the credit allocation in the relationship between financial development and economic growth for the selected Asian economies. Apart from this, the results also suggested that GCF, $\mathrm{BM}$ are critical proxies of financial development that contributes towards the economic growth of an economy.

The present study supports the framing of financial policies for improving the functions of financial markets in the long run. More precisely, the 
Table 5. The Panel ARDL Test

\begin{tabular}{|c|c|c|c|c|}
\hline Variable & Coefficient & Std. error & T-Stat & Probability \\
\hline \multicolumn{5}{|c|}{ Long-Run Equation } \\
\hline GCF & 5.77 & 1.04 & 5.52 & 0.00 \\
\hline BM & 4.75 & 1.19 & 3.96 & 0.00 \\
\hline DCPS & 86.40 & 613.90 & 0.14 & 0.88 \\
\hline DCBS & 103.78 & 921.19 & 0.11 & 0.91 \\
\hline \multicolumn{5}{|c|}{ Short-Run Equation } \\
\hline ContQ1 & -0.01 & 0.00 & -3.33 & 0.00 \\
\hline $\mathrm{D}(\mathrm{GCF})$ & 0.10 & 0.02 & 3.85 & 0.00 \\
\hline ContQ2 & 0.001 & 0.004 & 0.35 & 0.72 \\
\hline $\mathrm{D}(\mathrm{BM})$ & -0.15 & 0.06 & -2.37 & 0.01 \\
\hline ContQ3 & 0.001 & 0.00 & 1.50 & 0.13 \\
\hline $\mathrm{D}(\mathrm{DCPS})$ & -0.02 & 0.02 & -0.73 & 0.46 \\
\hline ContQ4 & 0.00 & 0.00 & 1.49 & 0.13 \\
\hline $\mathrm{D}(\mathrm{DCBS})$ & -0.01 & 0.02 & -0.64 & 0.51 \\
\hline
\end{tabular}

Table 6. Panel ARDL Cointegration Test (Wald Test)

\begin{tabular}{lccc}
\hline Variable & Test-Stat & Value & Probability \\
\hline GCF & F-Stat & 30.48 & 0.00 \\
BM & F-Stat & 15.73 & 0.00 \\
DCPS & F-Stat & 0.01 & 0.00 \\
DCBS & F-Stat & 0.01 & 0.00
\end{tabular}


Table 7. The Panel ARDL Test

\begin{tabular}{|c|c|c|c|c|}
\hline Variable & Coefficient & Std. error & T-Stat & Probability \\
\hline \multicolumn{5}{|c|}{ Long-Run Equation } \\
\hline$G C F=f(G D P)$ & 0.16 & 0.03 & 4.67 & 0.00 \\
\hline$B M=f(G D P)$ & 0.16 & 0.02 & 5.92 & 0.00 \\
\hline$D C P S=f(G D P)$ & 0.16 & 0.02 & 6.04 & 0.00 \\
\hline$D C B S=f(G D P)$ & 0.26 & 0.03 & 8.36 & 0.00 \\
\hline \multicolumn{5}{|c|}{ Short-Run Equation } \\
\hline $\mathrm{GCF}=\mathrm{f}(\mathrm{GDP})$ ContQ1 & -0.25 & 0.03 & -7.21 & 0.00 \\
\hline $\mathrm{D}(\mathrm{GDP})$ & 1.51 & 0.36 & 4.14 & 0.00 \\
\hline $\mathrm{DCPS}=\mathrm{f}(\mathrm{GDP})$ ContQ2 & -0.13 & 0.04 & -3.18 & 0.00 \\
\hline $\mathrm{D}(\mathrm{GDP})$ & 0.11 & 0.31 & 0.35 & 0.71 \\
\hline $\mathrm{DCBS}=\mathrm{f}(\mathrm{GDP})$ ContQ3 & -0.13 & 0.04 & -3.05 & 0.00 \\
\hline $\mathrm{D}(\mathrm{GDP})$ & 0.42 & 0.25 & 0.31 & 0.75 \\
\hline $\mathrm{BM}=\mathrm{f}(\mathrm{GDP})$ ContQ4 & -0.22 & 0.05 & -3.94 & 0.00 \\
\hline $\mathrm{D}(\mathrm{GDP})$ & -0.50 & 0.15 & -3.34 & 0.00 \\
\hline
\end{tabular}

Table 8. Granger Causality Test (Dumitrescu-Hurlin Test)

\begin{tabular}{lccc}
\hline Variables & W-Stat & Variables & W-Stat \\
\hline GCF \& GDP & 2.1 & GDP \& GCF & $6.2^{*}$ \\
BM\& GDP & $5.8^{*}$ & GDP\& BM & $6.8^{*}$ \\
DCPS \& GDP & 2.5 & GDP\& DCPS & $6.1^{*}$ \\
DCBS\& GDP & 2.6 & GDP\&DCBS & $6.2^{*}$
\end{tabular}


findings of the study backs the rational utilization of credit, as expansion of credit allows consumers and business ventures to borrow and spend more. This increase in consumption will eventually result in higher investment and will in-turn leads to creation of more jobs and thus, benefiting the economy as a whole. However, apart from making the credit system stronger, proper feedback and check on the meticulous utilization of the credit is also required with the intention that in the long run the credit allocated in the past should bear fruitful results in the presence of a cascading effect with a time lag.

The study strongly recommends that attention should be focused on long run policies, for example, raising the level of financialization of these economies.

Finally, with the changing warp and weft of the present economic situation many possible extensions for future research can also be made. Like researchers have also highlighted the significant role of savings in strengthening the relationship between financial development and economic growth (Jahan \& McDonald, 2011). However, the present attempt has not tested the savings aspect, so inclusion of this factor may uncover important relationship in terms of saving pattern and the economic growth aspect.

The findings of the study create a new dimension in the finance growth nexus which considers the vital role of finance for Asian economies.

\section{References}

Abu-Bader, S., \& Abu-Qarn, A. M. (2010). Financial development and economic growth: empirical evidence from MENA countries. Review of Development Economics, 12(4), 803-817.

Abu-Qarn, S., \& Abu-Bader, S. (2007). Sources of growth revisited: Evidence from selected MENA countries. World Development, 35(5), 752-71.

Acaravci, S. K., Ozturk, I., \& Acaravci, A. (2009). Financial development and economic growth: Literature survey and empirical evidence from Sub-Saharan African countries. South African Journal of Economic and Management Sciences, 12(1), 11-27.

Adusei, M. (2013).Financial development and economic growth: Evidence from Ghana. The International Journal of Business and Finance Research, 7(5), 61-76.

Agbetsiafa, D. K. (2003).The finance growth nexus: evidence from sub-Saharan Africa. International Advances in Economic Research, 9(2),172-89.

Ahmed, S. M., \& Ansari, M.L. (1998). Financial sector development and economic growth: The South Asian experience. Journal of Asian Economics, 9(3), 503-517.

Al, A. M. \& Harb, N. (2005).Financial development and economic growth in the Middle East. Applied Financial Economics, 15(15), 1041-1051.

Alesina, A., \& Rodrik, D. (1994). Distributive politics and economic growth. Quarterly Journal of Economics, 109(2), 465-90.

Alom, K. (2018). Financial development and economic growth dynamics in South Asian region. The Journal of Developing Areas, 52(4), 47-66.

Al-Yousif, K. Y. (2002). Financial development and economic growth. Another look at the evidence from developing countries. Review of Financial Economics, 11(2), 131-50.

Ang, J. B., \& McKibbin, W. J. (2007). Financial liberalization, financial sector development and growth: Evidence from Malaysia. Journal of Development Economics, 84(1), 1-19.

Arcand, J. L., Berkes, E., \& Panizza, U. (2015). Too much finance? Journal of Economic Growth, 20(2), 105-148. Arizala, F., Cavallo, E., \& Galindo, A. (2009). Financial Development and Tfp Growth: Cross-Country and Industry-Level Evidence. IDB Working Paper No. 568. https://ssrn.com/ abstract $=1821919$ or http://dx.doi.org/10.2139/ $\underline{\text { ssrn.1821919 }}$

Ayadi, R., Arbak, E., Naceur, S. B., \& De Groen, W. P. (2015). Financial development, bank efficiency, and economic growth across the Mediterranean. In R. Ayadi, M. Dabrowski, L. de Wulf (Eds.), Economic and social development of the Southern and Eastern Mediterranean countries (pp. 219-233). Springer.

Bakhouche, A. (2007). Does the financial sector promote economic development? The case of Algeria. Savings and Development, 31(1), 23-44.

Beck, T., Levine, R., \& Loayza, N. (2000).Finance and the sources of growth. Journal of Financial Economics, 58(2), 261-300

Ben, N. S., Ghazouani, S., \& Omran, M., (2008). Does stock market liberalization spur financial and economic development in the MENA region?, Journal of Comparative Economics, 36(4), 673-693.

Bena, J., \& Jurajda, S., (2007). Which firms benefit more from financial development? CERGE-EI Working Papers No. 330. The Center for Economic Research and Graduate Education - Economics 
Institute, Prague.

Benhabib, J., \& Spiegel, M. M. (2000).The role of financial development in growth and investment. Journal of Economic Growth, 5(4), 341-360.

Bhattacharya, P. C., \& Sivasubramanian, M. N. (2003). Financial development and economic growth in India: 1970-1971 to 1998-1999. Applied Financial Economics, 13(12), 925-929.

Bongini, P., Iwanicz-Drozdowska, M., Smaga P., \& Witkowski, B. (2017). Financial development and economic growth: The role of foreign-owned banks in CESEE countries. Sustainability, 9(335), $1-25$.

Breitung, J. (2000). The local power of some unit root tests for panel data. In B. Baltagi, T. B. Fomby, \& R. Carter Hill (Eds.), Advances in econometrics. Vol. 15, Nonstationary panels, panel cointegration, and dynamic panels (161-177) https://doi. org/10.1016/S0731-9053(00)15006-6

Breusch, T. S., Pagan, A. R.. (1980). The Lagrange multiplier test and its applications to model specification tests in econometrics. Review of Economic Studies, 47(1), 239-253.

Calderon, C., \& Liu, L. (2003). The direction of causality between financial development and economic growth. Journal of Development Economics, 72(1),321-34.

Canova, F., \& Ciccarelli, M. (2009). Estimating multicountry VAR models. International Economic Review, 50(3), 929-959.

Chakraborty, S., and Ray, T. (2006). Bank-based versus market-based financial systems: A growththeoretic analysis. Journal of Monetary Economics, 53(2),329-50.

Chandavarkar, A. (1992). Of finance and development: neglected and unsettled questions. World Development, 20(1), 133-42.

Chudik, A., \& Pesaran, M. H. (2013). Large panel data models with cross-sectional dependence: a survey. CAFE Research Paper, (13.15).

Darrat, A. F. (1999). Are financial deepening and economic growth causally related? Another look at the evidence. International Economic Journal, 13(3), 19-35.

De, G. J., \& Guidotti, P. E. (1995). Financial development and economic growth, World Development, 23(3), 433-48.

Demetriades, P. O., \& Hussein, K. A. (1996). Does financial development cause economic growth? Time-series evidence from 16 countries. Journal of development Economics, 51(2), 387-411.

Dumitrescu, E.-I. and Hurlin, C. (2012). Testing for
Granger non-causality in heterogeneous panels. Economic Modelling, 29(4).1450-1460.

Fase, M. M. G. (2001). Financial intermediation and long-run economic growth in the Netherlands between 1900-2000. Economologues, 85-98.

Fase, M. M., \& Abma, R. C. N. (2003). Financial environment and economic growth in selected Asian countries. Journal of Asian economics, 14(1), 1121.

Ghardallou, W. \& Boudriga, A. (2013).Financial development and democracy: Does the institutional quality matter?http://www.erudite.univ-paris-est. fr/evenements/colloques-et-conferences/atm2013-communications-full-papers/?eID=dam frontend_push\&docID $=25227$.

Ghirmay, T. (2004) .Financial development and economic growth in sub-Saharan African countries: Evidence from time-series analysis. African Development Review, 16(3), 415-432.

Goldsmith, R. W. (1969). Financial structure and development. Yale University Press.

Gouider, A. L., \& Trabelsi, M. (2005). Does financial market development matter in explaining growth fluctuations? Savings and development, 30(1), 469-89.

Granger, C. W. J. (1986).Developments in the study of cointegrated economic variables. Oxford Bulletin of Economics and Statistics, 48(3), 213-28.

Greenwood, J., and Smith, B. D. (1997). Financial markets in development and the development of financial market. Journal of Economic Dynamic and Control, 21(1), 145-181.

Gylfason, T., \& Zoega, G. (2006). Natural resources and economic growth: The role of investment. World Economy, 29(8), 1091-1115.

Habibullah, M. S., \& Eng, Y. K. (2006). Does financial development cause economic growth? A panel data dynamic analysis for the Asian developing countries. Journal of the Asia Pacific Economy, 11(4), 377-93.

Hadri, K. (2000). Testing for stationarity in heterogeneous panel data. Econometrics Journal, 3(2), 148-61.

Hassan, K. M., Sanchez, B., \& Yu, J. S. (2011). Financial development and economic growth: New evidence from panel data. The Quarterly Review of Economics and Finance, 51(1), 88-104.

Holden, P. \& Howell, H. (2009). Institutions and the legal framework for business development in the Caribbean. Private Sector Development Discussion Paper No. 3. Inter-American Development Bank. 
Holtz, E. D., Newey, W. \& Rosen, H. S. (1988). Estimating vector autoregression with panel data. Econometrica, 56(6), 1371-1395.

Howie, P. J., \& Kleczyk, E. J. (2007). New developments in panel data estimation: Full-factorial panel data model [Paper presentation]. American Agricultural Economics Association 2007 Annual Meeting, Portland, OR, United States.

Hsueh, S. J., Hu, Y. H. \& Tu, C. H. (2013). Economic growth and financial development in Asian countries: A bootstrap panel granger. Journal of Economic Modeling, 32(2), 294-301.

Hunady, J., Pisar, P., Musa, H., \& Musova, Z. (2017). Innovation support and economic development at the regional level: panel data evidence from Visegrad countries. Journal of International Studies, 10(3), 147-160.

Hussain, F., \& Chakraborty, D.K. (2012). Causality between financial development and economic growth: Evidence from Indian states. The Romanian Economic Journal, 15(35), 27-47.

Im, K. S., Pesaran, H. M. \& Shin, Y. (2003). Testing for unit roots in heterogeneous panels. Journal of Econometrics, 115(1), 53-74.

Jahan, S., \& McDonald, B. (2011). A bigger slice of a growing pie. Finance and Development, 48(3), 16-19.

Jeanneney, S. G., Hua, P., \& Liang, Z. (2006). Financial development, economic efficiency, and productivity growth: evidence from China, Developing Economies, 44, 27-52.

Kar, M., \& Pentecost, E. J. (2000). Financial development and economic growth in Turkey: further evidence on the causality issue. Universitäts-und Landesbibliothek

Sachsen-Anhalt. Khan, M. S., \& Senhadji, A. S. (2003). Financial development and economic growth: A review and new evidence. Journal of African Economies, 12(2), 89-110.

King, R. G., \& Levine, R. (1993). Finance and growth: Schumpeter might be right. Quarterly Journal of Economics, 108(3),717-37.

Konya, L. (2006). Exports and growth: Granger causality analysis on OECD countries with a panel data approach. Economic Modeling, 23(6), 978-92.

Kuznets, S. (1955). Economic growth and income inequality. American Economic Review, 45(1), 1-28.

Levin, A., Lin, C. F., \& Chu, C. S. (2002). Unit root tests in panel data: Asymptotic and finite-sample properties. Journal of Economics Metrics, 108(1), 1-24.

Levine, R. (1991). Stock markets, growth, and tax policy. Journal of Finance, 46(4), 1445-65.
Levine, R. (1997). Financial development and economic growth: Views and agenda. Journal of Economic Literature, 35(2), 688-726

Levine, R. (2005). Finance and growth: theory and evidence. Handbook of economic growth, 1, 865-934. Levine. R. (2005). Finance and growth: Theory, evidence, and mechanisms, In P. Aghion \& S. Durlauf (Eds.), The handbook of economic growth. North-Holland.

Levine, R., \& Zervos, S. (1999). Stock market development and long-run growth. The World Bank.

Levine, R., \& Zervos, S. (1998). Stock markets, banks, and economic growth. American Economic Review, 88(3), 537-58.

Liang, Q., \& Teng, J. Z. (2006). Financial development and economic growth: Evidence from China. China Economic Review, 17(4), 395-411.

Lucas, R. E. (1988). On the mechanics of economic development. Journal of Monetary Economics, 22(1), 03-42.

Luintel, K. B., \& Khan, M. A. (1999). Quantitative reassessment of the finance-growth nexus: Evidence from a multivariate VAR. Journal of Development Economic, 60(2), 381-405.

Maddala, G. S, \& Wu, S. (1999). A comparative study of unit root tests with panel data Korea Institute for international economic policy and a new simple test. Oxford Bulletin of Economics and Statistics, 61(1), 631-52.

McKinnon, R. I. (2010). Money and capital in economic development. Brookings Institution Press.

Mohsin, H. \& Rivers, P. (2010), Financial market integration of South Asian countries: Panel data analysis. International Journal of Economics and Finance, 3(2), 65-75.

Chakraborty, D., \& Mukherjee, J. (2012). Is there any relationship between foreign direct investment, domestic investment and economic growth in India? A time series analysis. Review of Market Integration, 4(3), 309-337.

Murari, K. (2017). Financial development-economic growth nexus: Evidence from South Asian middle-income countries. Global Business Review, 18(4), 924-935.

Ndikumana, L. (2000), Financial determinants of domestic investment in Sub-Saharan Africa: Evidence from panel data. World Development, 28(2), 381-400.

Odedokun, M. O. (1996). Alternative econometric approaches for analyzing the role of the financial sector in economic growth: Time-series evidence from LDCs. Journal of Development Economics, 
$50(1), 119-146$

Odhiambo, N. M. (2008). Financial depth, savings and economic growth in Kenya: A dynamic causal linkage. Economic Modelling, 25(4), 04-13.

Odhiambo, N. M. \& Muyambiri, B. (2018). South Africa's financial development and its role in investment. Journal of Central Banking Theory and Practice, 7(1), 101-120.

Ögren, A. (2008). The rationale of private note issuance: Note issuing commercial banks in the economic and financial development of nineteenth century Sweden. Working Paper No. 8. EconomiX/Université de Paris Ouest Nanterre La Défense. Economix Universite de Paris Ouest Nanterre La Defense, Working Paper No.8.

Onyele, K. O., \& Nwokoacha, E. B. (2016). Sources of public funds and economic prosperity: The Nigerian case. Journal of Business and Financial Affairs, 5(4), 1-11.

Pan, G., Jingyan, G. \& Qiaoling, J. (2016). The relationship between insurance sector and banking sector in china: Asymmetric granger causality test. Romanian Journal of Economic Forecasting, 19(2), 114-127.

Pata, U. K., \& Terzi, H. (2017). The Relationship between Renewable and Nonrenewable Energy Consumption and Economic growth in G7 countries: Evidence from Bootstrap Panel Causality Test. Acta Universitatis Danubius. Economica, 13(5).

Pesaran, M. H, \& Pesaran, B (1997). Working with Microfit 4.0: interactive econometric analysis. Oxford University Press.

Rajan, R.G., \& Zingales, L. (1998). Financial dependence and growth. The American Economic Review, 88(3), 559-86.

Rana, H. R., \& Barua, S. (2015). Financial development and economic growth: Evidence from a panel study on south Asian countries. Asian Economic and Financial Review, 15(10), 1159-1173

Rioja, F., \& Valev, N. (2004). Does one size tall?: a reexamination of the finance and growth relationship. Journal of Development Economics, 74(1), 429-47.

Robinson, J. (1952). The generalization of the general theory. In J. Robinson (Ed.), The rate of interest, and other essays (pp. 67-142). Macmillan.

Rodrik, D. (1999). Governing the world economy: Does one architectural style fit all? Brookings Trade Forum, 1999, 105-139.

Sarafidis, V., \& Wansbeek, T. (2012). Cross-sectional dependence in panel data analysis. Econometric Reviews, 3(1), 1-44.
Samargandi, N., Fidrmuc, J., \& Ghosh, S. (2015). Is the relationship between financial development and economic growth monotonic for middle income countries? World Development, 68, 66-81.

Schumpeter, J. (1911). The theory of economic development. Harvard University Press.

Shaw, E. (1973). Financial deepening in economic development. Oxford University Press.

Sharma, G. D., Rahman, M.M., Jain, M. \& Chopra, R. (2020) Nexus between energy consumption, information and communications technology, and economic growth: An enquiry into emerging Asian countries. Journal of Public Affairs. 1-13. e2172. https://doi.org/10.1002/pa.2172

Singh, A. (1997). Financial liberalization, stock markets and economic development. The Economic Journal, 107(442), 771-82.

Stem, N. (1989). The economics of development: a survey. The Economic Journal, 99(397), 597-685.

Waqabaca, C. (2004). Financial development and economic growth in Fiji. Economics Department, Reserve Bank of Fiji.

World Bank. (2013). World development indicators [Data set]. Washington DC, USA Available at: https://datacatalog.worldbank.org/dataset/worlddevelopment-indicators Accessed on 26th January 2015

World Bank. (2016). World development indicators [Data set]. Washington DC, USA Available at: https://datacatalog.worldbank.org/dataset/worlddevelopment-indicators Accessed on 26th August 2016

World Bank. (1989). World development report 1989. Oxford University Press.

World Tourism Organization (2014). World Tourism Indicators [Data Set]. Available at : https:// people.unica.it/carlamassidda/files/2012/04/UNWTO_Tourism-Highlight_2015.pdf Accessed on $30^{\text {th }}$ January 2015. 


\section{Appendix}

List of Asian Economies Selected in the Study

\begin{tabular}{lccc}
\hline S. No. & Countries & S. No. & Countries \\
\hline 1 & Bangladesh & 8 & Macao \\
2 & Bhutan & 9 & Malaysia \\
3 & China & 10 & Nepal \\
4 & India & 11 & Pakistan \\
5 & Japan & 12 & Saudi Arabia \\
6 & Jordan & 13 & Sri Lanka
\end{tabular}

